\title{
Póczik Szilveszter
}

\section{Embercsempészés, nemzetközi bünügyi együttmüködés, ítélethozatal}

\author{
Human smuggling, international cooperation \\ in criminal matters and sentencing
}

\begin{abstract}
Absztrakt
A korábbi embercsempész-szervezetek az elmúlt 20-30 évben jelentős átalakuláson mentek keresztül, alkalmazkodtak a gazdasági, politikai, jogi környezet változásaihoz. Magyarországon például a rendszerváltozás időszakában laza szervezettségben és alkalmilag tevékenykedő, kis létszámú, változó személyi öszszetételü embercsempészcsoportok mára professzionálissá váltak, és beilleszkedtek a nemzetközi hálózatok kapcsolatrendszerébe. Nemzetközi szinten a kibocsátó országokban tevékenykedő toborzók és szervezők képezik a hálózat gyökérzetét. A közbülső szinten többféle, olykor speciális helyismeretet és szaktudást igénylő feladatokat kell megszervezni és elvégezni, valamint ezek elvégzését ellenőrizni. A célországhoz közeledve a helyi szintü felderítésért és az utolsó köztes határátlépések, illetve végül a célországba történő belépés biztonságos végrehajtásáért a helyi szintü, szükségképpen már erősen konspirált és részfeladataiban funkcionálisan elkülönülő alegységekre és specialistákra bontott szervezet a felelős. Az embercsempészet finanszírozása bonyolult illegális pénzügyi műveletekkel történik, ezekben a kriptovaluták is szerepet kapnak. A bünüldözésnek a nemzetközi együttmüködés során számos eljárási és bizonyítási problémával, valamint a bizonyítékok törvényes beszerzését és felhasználhatóságát érintő nehézségekkel kell szembenéznie. A nemzetközi szervezettségben tevékenykedő bünözői hálózatok felderítése nemzetközi bünügyi együttmüködést igényel. A nemzetközi bünügyi együttmüködés egyik formája az EU-n belül a JIT-ként rövidített közös nyomozócsoportok megszervezése, amelyek határokon átnyúló nyomozásokat folytatnak. Innovatív megoldás, hogy a nyomozócsoport keretében más tagállam hatóságainak tagjai részt vehetnek egy adott tagállam eljárási cselekményeiben, és a kiküldött tag saját tagállamának illetékes hatóságát nyomozati cselekmény
\end{abstract}


elvégzésére kérheti fel. A nyomozócsoport által begyüjtött bizonyítékok felhasználhatók valamennyi részes tagállamban folyó büntetőeljárásban. Az Országos Kriminológiai Intézetben lefolytatott 2019. évi empirikus kutatás alapján megállapítható, hogy a magyar bíróságoknál embercsempészési ügyekben igen következetes, de differenciált ítélkezési gyakorlat érvényesül.

Kulcsszavak: szervezett bünözés, embercsempészet, nemzetközi bünöző hálózatok, migráció, illegális bevándorlás, felderítés, kriptovaluták, nemzetközi bünügyi együttmüködés, közös nyomozócsoport (JIT), ítélkezési gyakorlat

\begin{abstract}
Earlier human smuggler organizations have undergone a significant transformation by today, adapting to changes of the economic, political and legal environment of today. In Hungary, for example, loosely organized and occasionally operating human smuggler groups with changing personnel at the time of the change of regime, have become by now professional organizations integrated into international OC networks. Internationally, recruiters and organizers in the so called migration sending countries are at the root of the networks. At the intermediate level, a variety of special tasks requiring specific local knowledge and expertise need to be organized, performed and monitored. At the level of the local executors strongly conspired organizations are acting functionally separated into subunits and specialists for subtasks. Human trafficking is financed through complex illegal financial transactions, in which crypto-currencies play an important role, too. Law enforcement has to face a number of procedural and evidence problems in the international cooperation. Detecting international organized crime networks requires close international cooperation of police and judiciary authorities. One relatively new form of international criminal cooperation is the organization of JITs within the European Union that can carry out cross-border investigations. Within the framework of a joint investigation team, members of the authorities of another member state may take part in the proceedings of a given member state. The evidence gathered by the investigation team can be used directly in all participating member state. Based on the empirical research conducted at the National Institute of Criminology in 2019, it can be stated that the Hungarian courts have a very consistent but differentiated sentencing practice in human smuggling cases.
\end{abstract}

Keywords: organized crime, smuggling of people, international criminal networks, migration, illegal immigration, detection, crypto-currencies, international cooperation in criminal matters, joint investigation team (JIT), sentencing 


\section{Bevezetés}

Az embercsempészés (a Btk., azaz a 2012. évi C. tv. XXXIV. fejezet 353. §) a közigazgatás rendje elleni büncselekmények körébe tartozó, az illegális nemzetközi migrációhoz kapcsolódó reaktív deliktum, amely közbiztonsági és rendészeti kihívást is jelent egyszerre (Hautzinger, 2020). Semmiképpen nem öszszetévesztendő az emberkereskedelemmel (Btk. 192. §), amely többnyire az áldozat akarata ellenére, helyzetét kihasználva, gyakran kényszert, fenyegetést alkalmazva valósul meg, bár azzal büntetőjogi és rendészeti szempontból, valamint az elkövetés gyakorlati szempontjából szoros kapcsolatban áll. Az embercsempészés visszatérő vizsgálatának különös aktualitását a 2014/2015 fordulóján kirobbant európai migrációs válság adja. 2015 eleje óta a részben európai, részben Európán kívüli országokból Nyugat-Európába tartó illegális migránsok tömege súlyos humanitárius válságot idézett elő, és hathatós intézkedéseket követelt az érintett országok hatóságaitól csakúgy, mint az Európai Unió egészétől. Az UNHCR (az ENSZ Menekültügyi Főbiztosának Hivatala United Nations High Commissioner for Refugees) adatai szerint 2014 végére a határokon átlépve új hazát keresők száma elérte a 60 milliót (URL2).

A bevándorlástól leginkább sújtott országokban az illegális bevándorlás és az embercsempészet évtizedek óta probléma. Nagy-Britanniában például a lakosság többsége már 2006-ban súlyos problémának látta az illegális bevándorlást, amelynek során már ekkor halálesetek is történtek. A legtöbb bevándorló Törökországból, Szerbiából és Romániából érkezett. Az illegális bevándorlás visszaszorítása érdekében 2007-ben a britek jelentősen megnövelték a bevándorlással foglalkozó hivatalnoki kar létszámát, és szorosabbra vonták az együttműködést a szervezett bűnözés elleni hivatallal. A bevándorlók közel kétharmada illegálisan érkezett, mások vízumuk lejárta után maradtak az országban. Mintegy kétharmaduk Nagy-Britanniában korábban letelepedett ismerősök vagy rokonok révén talált illegális foglalkoztatót, kb. felük pedig középfokú végzettséggel rendelkezett, de felsőfokú végzettséget csak kevesen tudtak felmutatni (Windt, 2008). Németországban is milliós volt már 2007-ben az illegálisan beérkezők, illetve illegálisan ott tartózkodók száma. Olaszország korábban is az illegális migránsok egyik kedvelt célországa volt. A zöldhatárokon főleg Közép-Kelet-Európából és Ázsiából érkeztek Itáliába, de olykor Svájc és Franciaország felől is próbáltak bejutni az Észak-Afrikából és Dél-Amerikából érkezők. A tenger irányából jövők, főleg észak-afrikaiak és Srí Lanka-iak, Szicíliában és a környező szigeteken értek partot, a Törökország felől érkezők Calabriát, Lampedusát tekintették célpontnak, az albánok Apuliába igyekeztek hajón (Windt, 2008). Az illegális migránsok iskolázottsági összetétele máig nem 
sokat változott: többnyire húsz-harminc év közötti, alacsonyan képzett férfiak (Póczik, 2018), akik a jobb megélhetés reményében a jóléti államok egyikében, többnyire az Egyesült Királyság, Németország, Spanyolország, Ausztria, Svájc, Svédország területén szeretnének letelepedni és új életet kezdeni.

A háborúk, drasztikus politikai változások, valamint az éghajlatváltozás, környezeti katasztrófák, megélhetési válságok, nem utolsó sorban pedig a kiszélesült globális kommunikációs mechanizmusok és egyéb tényezők hatására hirtelen meglóduló nemzetközi illegális vándorlás kedvező lehetőséget nyújtott a szervezett bünözői hálózatok és csoportok számára. A legális nemzetközi migráció csatornáinak szükössége miatt az illegális (irreguláris) vándorlók magas kockázatokat vállalnak utazás közben. A vándorlók kiszolgáltatott helyzetét használják ki a bünelkövetők. A nemzetközi illegális migrációval kapcsolatos tapasztalatok hatására és a fenyegetések elhárítása érdekében a magyar jogalkotás új büntetőjogi tényállások, az úgynevezett határzáras büncselekmények bevezetésével reagált, egyben szigorította az embercsempészéshez kapcsolódó szankciókat (Póczik, 2018).

\section{Az embercsempész-hálózatok jellegzetességei}

Az embercsempészet összetett, magas szintủ technikai tudást és konspiratív szervezettséget feltételező büncselekmény, ezért az ezzel kapcsolatos szolgáltatás jellegü, látszólag legális vagy kifejezetten illegális tevékenységek, mint a valódi vagy hamis okmányok beszerzése, az illegális határátlépés szervezése és/vagy az ahhoz történő segítségnyújtás, az ideiglenes elhelyezés, az idegen országokon belüli és azokon át történő szállítás stb. tarifái igen magasak, és az igények és kockázatok fokozódásával növekszenek. A Frontex (Európai Határ- és Partvédelmi Ügynökség) becslése szerint a 2017-2019 időszakban az embercsempészek több, mint 330 millió eurót kerestek a Földközi-tenger nyugati és középső részén elkövetett büncselekményekből. Csak 2017 folyamán a migránsokat hajóval Olaszországba juttató csempészhálózatok migránsonként 1300 euróval számolva mintegy 135 millió eurót kerestek. Míg korábban a migránsok 1000-2000 eurót fizettek az Algériából vagy Marokkóból Spanyolországba történő szállításért, 2018 közepétől a díjak fejenként 3000 euróra emelkedtek, mivel az illegális migráció súlypontja a közép-mediterrán régió felöl a Földközi-tenger nyugati régiója felé kezdett elmozdulni (URL5). Fennáll a veszély, hogy a jövőben az embercsempészésre szakosodott bünözői hálózatok megnövekedett képességeik birtokában intenzívebb aktivitást mutatnak majd más büncselekményi 
területeken mint a pénzmosás, korrupció, árucsempészet, emberkereskedelem és terrorizmus (Frontex, 2020).

A korábbi embercsempész-szervezetek mára jelentős átalakuláson mentek keresztül, alkalmazkodtak a gazdasági, politikai, jogi környezet változásaihoz. Magyarországon a rendszerváltozás időszakában létrejött, lazán szervezett és alkalmilag tevékenykedő, kis létszámú, változó személyi összetételü embercsempészcsoportok mára professzionálissá váltak és beilleszkedtek a nemzetközi bűnözői hálózatok kapcsolatrendszerébe. E csoportok tagjai már a 20. század utolsó évtizedének közepére néhány tagból álló, viszonylag állandó kemény mag köré csoportosultak, majd kialakultak a stabil, vertikálisan és horizontálisan szerveződő hierarchikus embercsempész-szervezetek, amelyeknek hivatásos bünöző tagjai tervszerü munkamegosztással rendszeres illegális haszonszerzésre törekednek (Gaál, 2005). Helyi szinten ez a hierarchikus struktúra a hatékony konspiráció előfeltétele.

A nemzetközi embercsempész hálózatok ma már többrétegüek és sokarcúak, strukturális szinten formailag egyfelöl hálózat jellegüek, másfelől szervezetszerủek. Nemzetközi szinten a hálózat gyökerét a kibocsátó országokban tevékenykedő szervezők és toborzók alkotják, de róluk tudhatunk a legkevesebbet. A kibocsátó országokban, illetve régiókban székelő gyökércsoportok élén egymással közvetlen kapcsolatot tartó, rendszerint azonos nemzetiségü vagy nyelvü, gyakran rokoni kapcsolatban álló szervezők állnak. Tevékenységük célja, hogy megfelelő számú fizetőképes illegális migránst toborozzanak, és segítsék elindulásukat a célországok felé. Fedőszervként gyakran használnak legális utazási vagy munkaerő-közvetítő irodákat. Kapcsolatban állnak a regionális szervezőkkel, akik az illegális migrációs útvonalon fekvő országokban fejtik ki tevékenységüket.

A mai illegális migráció nagy földrajzi távolságokat ível át, számos közbülső áttétel révén müködik. A köztes csoportok gondoskodnak az illegális migránsok adott országba történő bejuttatásáról, elrejtéséről, pihentetéséről, a továbbszállítást végzőknek történő átadásról. A regionális, illetve végül a pontszerúen megjelölhető célterület felé közeledve a szervezettség egyre szigorúbb, szubordinációs alapú rendszerré merevedik, amelyben elkülönül a vezetői, összekötői és végrehajtói szint. A közbülső szinten többféle, olykor speciális helyismeretet és szaktudást igénylő feladatokat kell elvégezni, ezeket ellenőrizni, amit rendszerint mindkét kultúrában járatos személyek végeznek. Ilyen tevékenység egyebek között a kétnyelvü információtranszfer: a tolmácsok a kiinduló és a tranzit ország nyelvét egyaránt beszélő, bármilyen jogcímen, például valóságos vagy névházasság révén bevándorolt személyek, vagy ezek két anyanyelvủ utódai. Mivel nem szakemberek, fennáll az információvesztés vagy a téves közlés 
veszélye, ők maguk pedig szolgáltatásukkal olykor akaratlanul válnak bünsegéddé. Az ellenőrök felügyelik a szállítások biztonságát, ők felelnek a hatósági kapcsolatok rendezéséért, a megbízhatatlan közremüködők kiszüréséért és az utaztatott személyek és csoportok továbbításáert a közbeeső ország(ok)ban.

A célországhoz közeledve a helyi szintü felderítésért és az utolsó köztes határátlépések, illetve végül a célországba történő belépés biztonságos végrehajtásáért a helyi szintü, szükségképpen erősen konspirált és részfeladataiban funkcionálisan elkülönülő csoportokra és specialistákra bontott szervezet a felelös, amely időről időre személyes ismeretségi alapon beszervezett alkalmi segítőkre is támaszkodhat. Feladatuk az államhatáron való átjuttatás. Alaposan ismerik a határterület földrajzi, infrastrukturális helyzetét, a határőrizet szervezettségét, eljárásait és alsóbb rangú személyi állományát. E csoportokban külön személyek végzik a felderítést, a szállítást, az előfutó-biztosítást és a mélységi biztosítást, valamint a távoli megbízók informálását. Specialisták végzik a különféle okmányokkal kapcsolatos (például hamisítási) feladatokat, a „honoráriumok” beszedését, elosztását és továbbítását, ahogy ezt a kábítószerüzlet pénzügyi csatornái tekintetében is jól ismerjük.

A hálózatok központjai és a köztes, valamint helyi végrehajtó szervezetek között nincs közvetlen kapcsolat. A konspiráció követelményeinek megfelelően gyakran még a helyi szervezet sejtjei vagy tagjai sem ismerik egymást. A feladatokat és utasításokat távközlési eszközökön kapják. Korábban erre megfelelt a telefon és a kódolt beszéd, mára azonban ezek helyét - a hatóságok számára részben még ma is hozzáférhetetlen - mobil kommunikációs platformok, sőt olyan rafinált módszerek vették át, mint a webalapú szerepjátékok és játékkonzolok. Ezt igazolták az Országos Kriminológiai Intézetben lefolytatott 2019. évi célkutatás eredményei (Póczik, Bolyky \& Sárik, 2019). Az akkori vizsgálatból az is kiderült, hogy bár végrehajtói szinten számos embercsempészt sikerül leleplezni, a csempész szervezetek vezetői ellen igen nehéz eredményes büntetőeljárást folytatni, a végső mozgatóként működő szervezők pedig szinte elérhetetlenek, így érinthetetlenek. A 2019. évi kutatásból kiviláglott, hogy az embercsempészések túlnyomó többsége nagy biztonsággal bünszervezetek számlájára írható, de ezt rendkívül nehéz és gyakran nem is sikerül bizonyítani. A különféle migrációs utakon tevékenykedő embercsempész hálózatok, szervezetek és csoportok szervezettsége - különösen a funkcionális specializáció eltérései miatt - mutat bizonyos különbségeket, ezek azonban az általános képet nem befolyásolják.

Bár Magyarországon és régiónkban a 1990-es évtized végére az embercsempészés szervezett formája vált meghatározóan jellemzővé, az embercsempészési deliktumok minőségi jellemzői a külső körülmények változásának megfelelően 
és a kereslet fizetőképességének arányában változnak. Az általában alkalmazott módszer szerint a csempészek a csempészett személyeket a tranzit- vagy célállam szárazföldi vagy vízi határáig kísérik, azon átsegítik, a túloldalon pedig helyi segítők várják őket és jármüvel biztosítják továbbutazásukat. A tengeri régiókban, ahogy az utóbbi években tapasztaljuk, a rövid vízi utazást követöen átveszik őket egyes nem-kormányzati szervezetek (röviden NGO-k) migránstaxiként üzemelő hajói, partraszálláskor pedig átadják őket a - mentésre és átmeneti ellátásra kötelezett - hatóságoknak. Máig találkozunk alkalmi elkövetőkkel vagy alkalomszerüen összeállt amatőr csoportokkal is. Ahogy korábbról is ismert, az ilyen alkalmi elkövetés során ma is jellemző az államhatár taxival vagy magán gépkocsival való megközelítése, a járőrszolgálat megfigyelése, kikerülése, majd az államhatár gyalogos átlépése (Gál, 2005), illetve a gyalogos átkísérés, ami azonban hazánkban a határkerítés megépülésével igen megnehezült és kockázatossá vált. Ezért az alkalmi embercsempészek gyakran becsapják a migránsokat. „Megautóztatják”, majd valamely tranzitország mélységi területén magukra hagyják őket, azt hazudva, hogy már a célországban vannak. Az alkalmi embercsempészek a vándorlókat gyakran csak a célországgal szomszédos területekig vagy a célország külső határáig kalauzolják. Az utóbbiak onnantól magukra hagyva az ismeretlen terepen papír- vagy internetes térképek, vázlatok, jellegzetes tereptárgyak vagy előre gyártott tájékoztató füzetek alapján tájékozódnak. Informáltságuk azonban egyre javul (URL1). Sokan az államhatárt önállóan, általában kettő-ötfős kiscsoportokban gyalog igyekeznek illegálisan átlépni, kihasználva a sötét napszakokat, rossz látási viszonyokat és a terep adta elrejtőzési lehetőségeket.

\section{Elkövetési módszerek, másodlagos és kiegészítő büncselekmények}

Az embercsempészetet általában kiegészítő büncselekmények kísérik. Az embercsempészek az illegális migráns csoportokat gyakran személy- vagy tehergépjármủvekben, lakókocsikban, utánfutókban, vasúti kocsikban elrejtve vagy hamis úti okmányok segítségével kísérlik átszállítani a legális határátkelőhelyeken. Korábban előfordult, hogy lopott autót vagy lopott rendszámot használtak, de jármúveik ma már a megbízható azonosító módszereknek és elektronikus nyilvántartás alapú ellenőrzéseknek köszönhetően szinte kivétel nélkül jogtiszták. Szállításra használt jármüveiket azonban rendszeresen váltják, bérelt gépkocsikat vesznek igénybe. A tengeri migránstaxikat üzemeltető NGO-k ma már nem is leplezik saját és jármüveik identitását, céljuk egyértelmüen és deklaráltan a célországok népességének és gazdaságának átalakítása a migráció révén. 
Gyakori az úti okmányok kapcsán elkövetett közokirat-hamisítás. A hamis okmányok korszerü technikával készülnek. Számos ország nem fordít kellő figyelmet a visszaélések megakadályozására, okmányaik nem tartalmaznak a hamisíthatóságot kizáró biztonsági elemeket. Az embercsempészek alaposan felkészítik a migránsokat új okmányaik tartalmából, valamint arra, hogyan viselkedjenek, a hatóságok kérdéseire mit válaszoljanak, a származási országukra utaló jeleket, bankjegyeket, eredeti okmányokat, ruházati emblémákat és gyári jelzéseket pedig eltüntetik. A felkészítés gyakran tanfolyami oktatásként, kollektív ismeretátadással történik annak érdekében, hogy csoportos lebukás esetén egyforma történeteket adjanak elö. A csempészek saját önvédelmük érdekében gyakran gondoskodnak arról, hogy a csempészett személyek, ha akarnak se tudjanak felvilágosítást adni az elkövetés helyére és idejére vonatkozóan. Ezért gyakran megtévesztik őket, így nem tudják, melyik országban jártak korábban vagy járnak éppen, és nem ismerik arcról az elkövetőket sem. A migránsokat kísérő embercsempészek lebukás esetén az etnikai azonosságra és/vagy nyelvismeretre támaszkodva maguk is migránsnak adják ki magukat. Olykor több hamis személyazonosságot használnak. A migránsok kiléte sem azonosítható, mert semmilyen személyes dokumentumot nem tartanak maguknál, tanúskodás és vallomástétel esetén nem müködnek együtt a hatósággal, hiszen érdekazonosságot látnak maguk és az embercsempészek között. A végrehajtók az illegális átlépésre kiválasztott határ mindkét oldalán felderítést végeznek, és a határrendészet által legkevésbé őrzött határszakaszokat preferálják. Az elkövetés ideje rendszerint a késő éjszakai időszak. Az útvonalakat és pihenőhelyeket előkészítik, ellenőrzik. Az előfutók felmérik a szállítási útvonalat és veszély esetén a szállítójármüvet leállítják, elrejtik, vissza vagy más útvonalra irányítják. Pihenőhelyeket rendeznek be, fö- és tartalék útvonalakat jelölnek ki, előfutót vagy terepfigyelöt és fejlett technikai berendezéseket alkalmaznak. A kapcsolattartásban alkalmazott mobiltelefonokat rendszeresen cserélik vagy idegenek nevére vásárolt készüléket használnak, illetve visszatértek a fent említett internetes eszközök mellett a nyilvános telefonfülkéből vagy rádió adóvevőn bonyolított hívásokhoz. Az embercsempészés során a csempészett csoportok nagysága igen változó, a tengereken nagyobb, a szárazföldön egyre kisebb csoportokban történik. Az embercsempészek folyamatosan keresik és építik ki rendészeti kapcsolataikat, egyfelől az információszerzés érdekében, másfelől a megvesztegetés és büncselekményekbe történő bevonás lehetőségeit keresve, hiszen ezek a kapcsolatok profilváltás vagy alternatív bünözői tevékenység folytatása esetén jól kamatoztathatók a tiltott, hamis és/vagy magas jövedéki tartalmú csempészáruk szállításában és forgalmazásában is. 
A pihenőhelyek lehetnek a tulajdonos tudtával térítés ellenében vagy tudtán kívül igénybe vett magánbirtokok, házak, lakások, olcsó motelek, elhagyott mezőgazdasági vagy katonai épületek, amelyek a határátlépés tervezett helyszínéhez közel, de félreeső helyen találhatók. Az elkövetők általában gondoskodnak az illegális migránsok szigorú őrzéséről és ellátásáról. Az embercsempészek körében ismert az „,ismételt begyüjtés” módszere: az illegális migránsokat ráveszik, hogy a határátlépést követően kérjenek menedéket a menekültügyi hatóságnál, majd a befogadó állomásokon vagy azok környékén szervezik meg vagy újjá a migráns transzporokat. Tehát lényegében a menekültügyi befogadó központokat használják pihenő állomásként.

\section{Pénzforgalom, finanszírozás és pénzmosás az embercsempészetben és azon túl}

Az embercsempészek induláskor olykor csak előleget kérnek, az áldozatok pedig utólag fizetik ki a fennmaradó hátralékot, vagy ledolgozzák az adott összeget (ez azonban már az emberkereskedelem tárgykörébe tartozik). A migráció magas költségei és kockázatai okán a migránsok körében gyakori az illegális munkavállalás és más jogellenes cselekmények elkövetése: koldulás, prostitúció, haszonszerzésre irányuló és/vagy erőszakos büncselekmények (Póczik, 2017). A migráció, egyebek között az illegális migráció sajátos finanszírozási formája a különösen Kelet-Ázsiában és az arab világban elterjedt hawala rendszer (Málnássy, 2016), amely eredeti jelentésében a bizalmon alapuló fizetések rendszere, de elterjedt a terrorfinanszírozás, valamint a korrupciós és kábítószerekből származó pénzforgalom módszereként is. E régi intézmény már a keresztes háborúk idejében ismert volt, és az európai bankrendszer őseként is tekinthetünk rá. Ennek ellenére ma illegális pénzügyi szolgáltatásnak, tiltott banki tevékenységnek, sőt pénzmosásnak minősül. Sok-sok közvetítő bevonásával müködik, és nagyban támaszkodik családi vagy regionális kapcsolatokra. Alkalmazásakor pénzmozgás csak a kapcsolati lánc végein történik. A küldő fél megkeresi a közvetítőt (hawaldar) és átadja neki az összeget, aki kapcsolatba lép partnerével a célországban, és közli vele, kinek mekkora összeget kell kifizetnie. Mindkét közvetítő levonja saját jutalékát, a címzett pedig - a hatósági ellenőrzés lehetőségének kiküszöbölésével - felveszi a számára küldött pénzt egy telefonon kapott hitelesítő kód segítségével. Előnye az anonimitás, az alacsony jutalék és a bankokénál kedvezőbb valutaváltási árfolyam. A közvetítők sokrétủ kapcsolatban állnak és különféle ügyletek szaldóját számolják el egymás közt. A nyilvántartás csupán „kockás füzetben” történik, ezért szinte lehetetlen felgöngyölíteni. 
Hasonló a helyzet az utóbbi néhány évben létrejött kriptovalutákon alapuló fizetési rendszerekkel. Bűnözői körökben a bitcoin a legkedveltebb. Előnye az anonimitás, decentralizáltság, hogy lefoglalhatatlan és azonnali fizetést tesz lehetővé, bár a hagyományos valutákra történő átváltás már körülményesebb. A darkneten müködő feketepiacokon a kriptovaluták bevett fizetőeszközök. Az egyik legnagyobb digitális feketepiacon, az AlphaBayen 350 ezer különböző illegális terméket lehetett vásárolni bitcoin segítségével. A bitcoin tranzakciókat érintő kutatás eredménye szerint mintegy 24 millióan használnak bitcoint illegális célokra, vagyis az összes használó negyede. Évente 36 millió illegális tranzakció történik, ami az összes tranzakció 44\%-a, ezek összértéke évi 72 milliárd dollár, vagyis az összes tranzakció értékének ötöde. A tranzakciók mellett a bitcoin büncselekmények esetében, például a terrorcselekmények finanszírozásában is szerepet játszhat, vagy a zsarolóvírusok esetében, amikor is az elkövetök a titkosítás feloldásáért valamely kriptovalutában követelik a fizetséget (URL3). A kriptovalutákat ezek tisztázatlan jogi státusza teszi alkalmassá a pénzmosásra. Önmagában az is vitatott, pénzként vagy tulajdonként kell-e definiálni őket, és kell-e hozzájuk banki infrastruktúrát rendelni. Ha nem, akkor a digitális pénz nem lehet tárgya a pénzmosás elleni mechanizmusok vizsgálatának, ebben azonban szintén vita van. ${ }^{1}$

\section{A felderítés nehézségei, a nemzetközi bünügyi együttmüködés és a közös nemzetközi nyomozócsoportok}

A nemzetközi szervezettségben tevékenykedő bűnözői hálózatok felderítése nemzetközi együttmüködést igényel. A nemzetközi együttmüködés egyik formája a rendőri/nyomozati együttmüködés, másik formája az igazságügyi együttmüködés. A rendőri/nyomozati együttmüködés az Interpol (International Criminal Police Organization, 194 országot tömörítő nemzetközi bünüldöző és információs szervezet) közbejöttével az úgynevezett SIENA rendszeren (Secure Information Exchange Network Application - Biztonságos Információcsere-Hálózati Alkalmazás) folytatott kommunikáció útján történik. Az igazságügyi együttmüködés részben a nemzetközi egyezményeken alapuló jogsegélyforgalommal, részben a közös nyomozócsoportok, úgynevezett JIT-ek (Joint Investigation Teams) felállításával valósul meg. Az Európai Unió tagállamai közötti jogsegélyforgalom a kölcsönös bünügyi jogsegélyről szóló 2000.

1 A kriptovaluták tekintetben az EU terrorizmus elleni küzdelemről szóló 2017/541 irányelve, illetve a pénzmosás megelőzéséről szóló 2015/849 irányelv ma már nyilvánvalóan revízióra szorul. 
májusi EU jogsegélyegyezmény alapján bonyolódik. ${ }^{2} \mathrm{~A}$ harmadik államokkal folytatott jogsegélyi együttmüködés alapja az 1959. április 20-án kelt kölcsönös bünügyi jogsegélyről szóló európai egyezmény (Strasbourgi Egyezmény). ${ }^{3} \mathrm{Az}$ uniós jogsegélyegyezmény közvetlen jogsegélyforgalmat tesz lehetővé, ezzel szemben a Strasbourgi Egyezmény szerint a jogsegélyek forgalma az érintett államok központi hatóságain - elsősorban az igazságügyi minisztériumokon keresztül, a kérés teljesítése pedig a megkeresett állam joga alapján történhet. Előzetesen vizsgálni kell, hogy a jogsegélyi kérelemben foglalt cselekmény a megkereső és megkeresett állam joga szerint egyaránt büncselekménynek minősül-e. További lehetőséget nyújt a jogsegélyi együttmüködésre a Schengeni Végrehajtási Egyezmény 53. cikke, amely szerint a szerződő felek igazságügyi hatóságai a jogsegély iránti kérelmeket egymás között közvetlenül megküldhetik, és az azokra adott válaszokat ugyanilyen módon küldhetik vissza. Ezeken kívül léteznek kétoldalú jogsegélyegyezmények is.

A több államra kiterjedően tevékenykedő nemzetközi bünszervezetek ügyében a nyomozati és igazságügyi együttmüködés hatékony eszköze a kölcsönös elismerésen (Farkas, 2016) és bizalmon alapuló közös nyomozócsoport (JIT) jogintézménye. A JIT több állam nyomozó és igazságügyi tisztviselőből összeállított egység, amelyet írásbeli megállapodással meghatározott célra és időtartamra hoznak létre, hogy a részes tagállamok területén bünügyi nyomozást folytasson. A JIT-ek létrehozása akkor indokolt, ha a már megkezdett nyomozati eljárásban a több tagállamra kiterjedő büncselekmény felderítése rendkívül bonyolult, és az adott büncselekmény tárgyában a több tagállamban folyó nyomozások öszszehangolása elengedhetetlen. Konkrétan, ha nagy ráfordítást igénylő, határokon átnyúló, más tagállamokat is érintő bünügy nyomozása szükséges, amely az érintett tagállamok nyomozati cselekményeinek szoros összehangolását teszi szükségessé, és ezt az adott bünszervezet összetettsége és tevékenységének kifinomultsága megköveteli (Útmutató, 2017). Jellemzően ilyen büncselekmények az embercsempészés, az ember- és kábítószer-kereskedelem, valamint a nemzetközi pénzmosás, illetve más pénzügyi, áfa- és adócsalások (Bezsenyi et al., 2015). E közös nyomozócsoportok felállítása a kezdeti idegenkedés elmúltával a 2010 utáni periódusban jött igazán lendületbe (Rijken, 2006). Az évtized végére már közel száz befejezett nyomozásban vettek részt közös nyomozócsoportok. A magyar nyomozóhatóság 2011-ben vett elöször részt ilyen közös nyomozócsoportban. Ezek azóta idehaza is igen sikeresnek bizonyultak (Schmidt, 2017).

2 Az Európai Unió tagállamai közötti kölcsönös bünügyi jogsegélyről szóló 2000. május 29-én kelt egyezmény és az egyezmény 2001. október 16-án kelt kiegészítő jegyzőkönyve. Lásd 2005. évi CXVI. törvény.

3 Magyarországon kihirdette az 1994. évi XIX. törvény. 
Az Európai Unióban a JIT-ek létrehozása az EU jogsegélyegyezmény 13. cikke és az Európai Tanács közös nyomozócsoportokról szóló 2002. június 13-i kerethatározata alapján történik. ${ }^{4} \mathrm{~A}$ közös nyomozócsoport keretében a részes államok nyomozóhatóságai közvetlenül adhatják át egymásnak a rendelkezésre álló bizonyítékokat és egymás területén saját országuk joga szerint végezhetnek nyomozási cselekményeket, illetve aktívan részt vehetnek a társhatóság eljárási cselekményeiben. A JIT-ek meghatározott, de meghosszabbítható időre jönnek létre. Munkájuk befejezésekor a tagok értékelik az elvégzett munkát és az együttmüködés hatékonyságát. A közös nyomozócsoportok szakértői hálózata 2005 óta tevékenykedik (Xanthaki, 2006), és időről időre útmutatókat ad ki annak érdekében, hogy előmozdítsa a közös nyomozócsoportok alkalmazását. Minden tagállam egy vagy több igazságügyi és vagy bünüldözési szakértőt jelöl ki, akik nemzeti kapcsolattartó pontként és tanácsadóként munkálkodnak. A szakértői hálózat külön útmutatót állított össze a pénzügyi kérdések rendezéséhez (Titkárság, 2018). Az Európai Unió Büntető Igazságügyi Együttműködési Ügynöksége, vagyis az Eurojust feladata a tagállamok igazságügyi hatóságai közötti stratégiai és operatív eszközökkel történő koordináció a több tagállamban folyó nyomozások és a büntetőeljárások terén, főként a kölcsönös jogsegély és az európai elfogatóparancs révén (Szijártó, 2019). Az Eurojust segítséget nyújt a közös nyomozócsoportok szakértői hálózatának tevékenységéhez is (Útmutató, 2017).

A bünüldözésnek a nemzetközi együttmüködés során számos eljárási és bizonyítási problémával, valamint a bizonyítékok törvényes beszerzését és felhasználhatóságát érintő nehézséggel kell szembenéznie. A jogsegélyi eljárások hosszadalmasak, és az így beszerzett bizonyítékok felhasználhatósága gyakran kétséges, különösen, ha a partnerország jogrendje, illetve eljárásjoga eltér az Európai Unióban elfogadott elvektől. Bár a jogsegélyforgalomban beszerzett bizonyítékok problémamentesen felhasználhatók, a beszerzés folyamata lassú és bürokratikus még akkor is, ha a partnertestületek között bizalmi kapcsolat áll fenn. A több államot érintő ügyekben előfordul joghatósági és illetékességi ütközés. Gyakorlati problémát jelentenek a magas fordítási költségek és a fordítás nehézségei. Az embercsempészek gyakran több nyelvet, köztük ritka nyelveket vagy dialektusokat beszélő emberek, kommunikációjuk fordítása különleges ismereteket igényel, a lehallgatott telefonbeszélgetések pedig gyakran használhatatlanok a bünüldözők számára. Schmidt Gábor az embercsempészés tárgyában indult ügyek kapcsán felhívja a figyelmet arra az érdekkonfliktusra, amely

4 Lásd az Európai Unió tagállamaival folytatott bünügyi együttmüködésről szóló 2012. évi CLXXX. törvény, különösen 70/A-70/H §§. 
egyrészt az eljárási garanciákat betartó büntetőeljárás, valamint a bünszervezet teljes felszámolása, valamennyi szállítás vád tárgyává tétele, azaz a legalitás elve és a perökonómia között húzódik (Schmidt, 2017).

A magyar részvétellel megvalósult nemzetközi bünügyi együttmüködés ékes példája volt a 71 ember halálát okozó parndorfi halálkamion esetének kivizsgálása. A nyomozás a Nemzeti Nyomozó Iroda vezetésével és a Kecskeméti Járási és Nyomozó Ügyészség, majd a Bács-Kiskun Megyei Főügyészség felügyeletével a 2015. augusztus 27-én az osztrák Parndorf község közelében leparkolt kamionban holtan talált migránsok haláláért felelős bünszervezet ellen indult, a csempészett személyek sanyargatásával, üzletszerủen elkövetett embercsempészés büntette, valamint különös kegyetlenséggel, több ember, részben tizennegyedik életévét be nem töltött személyek sérelmére elkövetett emberölés büntette miatt. A magyar hatóságok a 2015 szeptemberében az Eurojustnál tartott koordinációs értekezleten közös nyomozócsoport felállítását javasolták, de a német hatóságok vonakodása miatt maradt a jogsegélyi együttmüködés lehetősége. A 2015 augusztusától egy éven át folyó egyeztetés az ügyben érintett országokkal hatékony nemzetközi együttmüködést eredményezett. A nyomozás megállapítása szerint a 2015. augusztus 26-án az osztrák rendőrök, az A4-es autópálya mellett félreállított furgonra bukkantak, melynek rakterében talált halottak, köztük nyolc nő és négy gyerek, útközben, még magyar területen megfulladt. Az elkövetők egy 14 tagú nemzetközi embercsempész csoport tagjai voltak, akik 31 esetben, mintegy 1200 embert csempésztek Németországba, ami a vezetők számára kb. 300000 euró bevételt hozott. Szállítási módszereik rendre veszélyeztették a migránsok életét. A csempészek tudták, hogy az utasok megfulladhatnak, mégsem álltak meg, attól tartva, hogy nem kapják meg a beígért ezer eurót. A sértettek az indulás után hamarosan dörömbölve jelezték, hogy elfogyott a levegőjük. A bolgár soförök telefonon értesítették afgán főnöküket, aki azonban megtiltotta, hogy megálljanak, kinyissák az ajtót és vizet adjanak a bent lévőknek. Azt az utasítást adta, ha meghalnak, tegyék ki őket valahol az erdőben. A tragédia után a csoport még két szállítmány elindítását tervezte, de időközben őrizetbe kerültek.

Mint kiderült, a 2015 elejétől augusztusig müködő bünszervezetet afgánok irányítottak, bolgár középvezetők, libanoni jármübeszerzők, valamint bolgár előfutók és szállítók vettek részt benne. Köztük szigorú hierarchia és feladatmegosztás érvényesült. A magyar hatóságok már a nyomozás elején elfogták a bünszervezet vezetőjét, a négy szervezőt és a kamion sofőrjét. Az elkövetők állampolgársága és kapcsolatrendszere nemzetközi bünszervezetre utalt. A csoport ellen már büntetőeljárások folytak Németországban, Ausztriában, Bulgáriában és Szerbiában is. A holtan talált 71 migráns, valamint az egy nappal később 
szintén majdnem halálos kimenetelü embercsempészés ügyében Ausztriában indult büntetőeljárást a magyar Legfőbb Ügyészség 2015 novemberében átvette. A nyomozás megállapította, hogy a migránsokat a szerb-magyar államhatáron illegálisan léptették be Magyarországra a bünszervezet Szerbiában tevékenykedő tagjai. A Szerbiából és Bulgáriából jogsegély útján beszerzett, származásra, állampolgárságra és büntetett előéletre vonatkozó bizonyítékok alapján a nemzetközi bünöző csoport valamennyi tagját és minden embercsempész szállítását sikerült felderíteni.

\section{Ítélkezés}

A 2019. évi kutatás során 76 jogerős ítélet vizsgálata alapján megállapítottuk, hogy a magyar bíróságoknál embercsempészési ügyekben igen következetes, de differenciált ítélkezési gyakorlat érvényesül, ami az önálló elkövetők, a kiscsoportban tevékenykedők és a nagy létszámú bünszervezetek tagjainak eltérö megítélésében mutatkozik meg. A bünszervezet keretében megvalósított büncselekmények elkövetőivel szemben a kiszabható büntetési tétel felső határa a kétszeresére emelkedik ${ }^{5}$, és a szabadságvesztés büntetés fegyházban hajtandó végre ${ }^{6}$ - a feltételes szabadulás lehetőségének kizárásával ${ }^{7}$-, emellett a Btk. egyéb súlyosabb következményeket is felsorol. Tekintve a bünszervezetben elkövetéshez kapcsolódó rendkívüli hátrányokkal járó büntetési lehetőségeket, tapasztalatunk szerint a bírák a szigorú törvényi rendelkezések szem elött tartásával, de igen nagy körültekintéssel szabják ki a büntetéseket, sokszor alkalmazva az enyhítő szabályokat. Erre példa, amikor az első büntényes önálló elkövetők esetében a bírák az egyébként következetesen alkalmazott végrehajtandó szabadságvesztés büntetést gyakran felfüggesztik, és az elítéltet próbára bocsátják. A külföldi elkövetőket szinte kivétel nélkül legalább négy évre kiutasítják Magyarország területéről. Magyar elkövetők esetében gyakori a jelentős összegü pénzbüntetés és vagyonelkobzás kiszabása. A kiszabott büntetés szigorúságát elsősorban az embercsempészés büncselekmény elkövetésének rendszeressége, a bünszervezetben tevékenykedés időtartama, a részvétel minősége és az elkövetés módja határozza meg. A hosszabb ideje tevékenykedő elkövetőkkel szemben súlyosabb szankciót alkalmaz a bíróság, a bünsegédi minőség viszont a bünszervezetben tevékenykedés esetén is enyhítő körülményként minősül.

5 Btk. 91. § (1) bekezdés.

6 Btk. 37. § (3) bekezdés bb.) pont.

7 Btk. 38. $\S$ (4) bekezdés c) pont, 44 . $\S(2)$ bekezdés b) pont. 
A csempészett személy sanyargatásával megvalósuló cselekményeket súlyosabban büntetik, mint az ugyanolyan büntetési tétellel fenyegetett és gyakran előforduló üzletszerü elkövetést (Póczik et al., 2019).

A büntetések kiszabásának differenciáltságát jól tükrözi a parndorfi ügyben idehaza, a Szegedi Ítélőtáblán 2019. június 20-án született jogerős ítélet. Az elsőrendü, afgán állampolgárságú vádlott, aki korábban oltalmazottként élt Magyarországon egy magyar állampolgárral élettársi kapcsolatban, valamint a másodrendủ bolgár vádlott embercsempészés büntette és emberölés büntette miatt a feltételes szabadságra bocsátást kizáró életfogytig tartó fegyházbüntetést (TÉSZ) kapott. A szállítmányt előfutóként biztosító bolgár harmadrendủ vádlott életfogytiglani fegyházbüntetéséből legkorábban harminc év múlva szabadulhat. A hütőkamion bolgár vezetője - negyedrendü vádlottként - szintén (tényleges) életfogytig tartó fegyházbüntetésben részesült. Az ötöd- és hatodrendü vádlott büntetése hat, illetve öt év börtönben letöltendő szabadságvesztés lett. A szökésben lévő hetedrendủ vádlottra a bíró bűnszervezetben elkövetett embercsempészés és 67 rendbeli társtettesként elkövetett életveszélyt okozó testi sértés büntette miatt nyolc év börtönbüntetést szabott ki. A nyolcad-, kilenced-, tized- és tizenegyedrendủ vádlottak ítélete négyéves börtönbüntetés lett. A szintén szökésben lévő tizenkettedrendủ vádlott nyolc év börtönt kapott, a tizenharmad rendủ vádlottat ötéves börtönbüntetésre ítélték. A Franciaországban elfogott tizennegyed rendü bolgár vádlott társtettesként, folytatólagosan elkövetett embercsempészés miatt négy év fegyházbüntetésben részesült. Négy év és nyolc hónap tartamú fegyházbüntetést kapott az a később elfogott bolgár férfi, aki ezer euróért legalább hat személyt szervezett be az embercsempészés megvalósításába, köztük a negyedrendủ vádlott sofőrt és a harmadrendủ előfutót (URL4).

\section{Összegzés}

Az országhatárok szigorú ellenőrzése és az illetéktelen behatolókkal szembeni védelme a modern közigazgatási intézmények kialakulása óta elsődleges fontosságú. Annál fontosabb, minél nagyobb számú tömeg igyekszik jogellenes módon belépni egy idegen ország területére. Ezért nem meglepő, hogy mára az idegenek illegális bejuttatása egy adott országba a bünözés más, magasabb ismereteket és szervezettséget igénylő ágaihoz hasonlóan kvázi szakmává vált, betagozódott a nemzetközi szervezett bünözői hálózatokba, és mind technikai, mind szervezeti tekintetben folyamatosan fejlödik. Ezt a folyamatot felgyorsította a vasfüggöny leomlása és a feltartóztathatatlan globalizáció. Az elmúlt évtizedekben a korábbi embercsempész-szervezetek jelentős átalakuláson 
mentek át, alkalmazkodtak a gazdasági, politikai, jogi környezet változásaihoz. Magyarországon a rendszerváltozást követő években lazán szervezett és alkalmilag tevékenykedő csoportok müködtek. Ezek a kis létszámú, változó személyi összetételủ embercsempész csoportok mára professzionálissá váltak, és beilleszkedtek a nemzetközi hálózatok kapcsolatrendszerébe. Nemzetközi szinten a kibocsátó országokban tevékenykedő toborzók és szervezők képezik a hálózat gyökérzetét. A közbülső szinten többféle, olykor speciális helyismeretet és szaktudást igénylő feladatokat kell megszervezni és elvégezni, valamint ezek elvégzését ellenőrizni. A célországhoz közeledve a helyi szintü felderítésért és az utolsó köztes határátlépésekért, illetve végül a célországba történő belépés biztonságos végrehajtásáért a helyi szintü, szükségképpen már erősen konspirált és részfeladataiban funkcionálisan elkülönülő alegységekre és specialistákra bontott szervezet a felelős. Az embercsempészet finanszírozása bonyolult illegális pénzügyi műveletekkel történik, ezekben a kriptovaluták is szerepet kapnak. A bűnüldözésnek a nemzetközi együttmüködés során számos eljárási és bizonyítási problémával, valamint a bizonyítékok törvényes beszerzését és felhasználhatóságát érintő nehézségekkel kell szembenéznie. A nemzetközi szervezettségben tevékenykedő bünözői hálózatok felderítése nemzetközi bünügyi együttmüködést igényel. Az EU tagállamai közötti bünügyi együttmüködés egyik, mára igen eredményesnek bizonyult formája a JIT-ek megszervezése, amelyek határokon átnyúló nyomozásokat folytatnak. E közös nyomozócsoportokban két vagy több tagállam hatóságainak tagjai jogosultak részt venni bármely részes tagállam eljárási cselekményeiben, a kiküldött tag pedig saját tagállamának illetékes hatóságainál nyomozati cselekményeket kezdeményezhet. A nyomozócsoport által beszerzett bizonyítékok valamennyi részes tagállamban folyó büntetőeljárásban felhasználhatók. Az empirikus kutatás rávilágított arra, hogy a magyar bíróságoknál embercsempészési ügyekben igen következetes és differenciált ítélkezési gyakorlat érvényesül. Ezt támasztja alá a parndorfi halálkamion elkövetőinek ügyében hozott jogerős ítélet is.

\section{Felhasznált irodalom}

Bezsenyi T. (2018). A közös nyomozócsoportok hatékonysága az emberkereskedelem elleni küzdelemben. In Frigyer L. (Szerk.), Nemzetközi jellegü szervezett bünözés nyomozásának kutatása információáramlási szempontból I.: Tanulmánykötet (pp. 64-84). Nemzeti Közszolgálati Egyetem.

Farkas Á. (2016). A kölcsönös elismerés elve az európai büntetőjogban I. Ügyészségi Szemle, 1, 93-94. 
Frontex (2020). Risk Analysis for 2020. Office of the European Union. https://frontex.europa.eu/ assets/Publications/Risk_Analysis/Risk_Analysis/Annual_Risk_Analysis_2020.pdf

Gaál Gy. (2005). Az embercsempész tevékenység megjelenési formáinak és módszereinek változásai a Magyar Köztársaság államhatárán 1991-2003 között. Doktori értekezés. Zrínyi Miklós Nemzetvédelmi Egyetem.

Hautzinger Z. (2020). A migráció szabályozásának reaktív tényezői. Belügyi Szemle, 68(9), 4762. https://doi.org/10.38146/BSZ.2020.9.3

Málnássy A. (2016). Az európai külföldi harcosok és az Iszlám Állam támogatói által használt terrorfinanszírozási módszerek. Terror és Elháritás, 2, 42-61.

Póczik Sz. (2017). A migrációspecifikus bűnelkövetés néhány aspektusáról. Kriminológiai Tanulmányok, 54, 155-180.

Póczik Sz. (2018). A határzárral kapcsolatos büncselekmények elkövetőinek szociológiai vizsgálata a Csongrád megyei büntetőeljárások alapján. Kriminológiai Tanulmányok, 55, 10-28.

Póczik Sz., Bolyky O. \& Sárik E. (2019). Migrációs válság, embercsempészés, büntetéskiszabás. Ügyészek Lapja, 26(6), 35-58.

Rijken, C. (2006). Joint Investigation Teams: Principles, Practice, and Problems - Lessons Learnt from the First Efforts to Establish a JIT. Utrecht Law Review, 2, 99-118. https://doi. org/10.18352/ulr.28

Schmidt G. (2017). Tradíciók versus hatékonyság - Nemzetközi együttmüködés a szervezett embercsempészés miatt indult bünügyekben. Ügyészek Lapja, 24(5), 79-90.

Szijártó I. (2019). Az Europol és az Eurojust szerepe a közös nyomozócsoportokban. Ügyészek lapja, 26(6), 59-73.

Titkárság (2018). JITs-Funding-Guide_HU. A közös nyomozócsoportok finanszirozási útmutatója. Közös Nyomozócsoporti Hálózat Titkársága. 08/01/2018, 3. verzió. https://www.eurojust. europa.eu/sites/default/files/Partners/JITs/JITs-Funding-Guide_HU.pdf

Útmutató (2017). Közös nyomozócsoportok - Gyakorlati útmutató. Az EU Tanács Főtitkársága, Brüsszel, február 14. https://docplayer.hu/106478118-6128-1-17-rev-1-mlh-tk-ia-dg-d-2b.html

Windt Sz. (2008). Legális és illegális bevándorlás az Európai Unió néhány fontosabb országában. In Póczik Sz. \& Dunavölgyi Sz. (Szerk.), Nemzetközi migráció - nemzetközi kockázatok (pp. 181-424). HVG-ORAC Lap- és Könyvkiadó Kft.

Xanthaki, H. (2006). Eurojust: Fulfilled or Empty Promises in EU Criminal Law? European Journal of Law Reform, 8(2-3), 175-197.

\section{A cikkben található online hivatkozások}

URL1: Egyre magasabb szintü támogatás állhat a migránsok mögött. https://www.origo.hu/ itthon/20200201-bakondi-gyorgy-egyre-magasabb-szintu-tamogatas-allhat-a-hatarsertokmogott.html 
URL2: The Global Refugee Crisis, Region by Region. https:/www.nytimes.com/interactive/ 2015/06/09/world/migrants-global-refugee-crisis-mediterranean-ukraine-syria-rohingya-malaysia-iraq.html?mtrref=undefined \&gwh=ADBF01CE8015D0D08138F87D0296C74B\&gwt=pay\&assetType $=$ PAYWALL

URL3: Bitcoin, a modernkori bünözők tulipánja? https://arsboni.hu/bitcoin-a-modernkori-bunozok-tulipanja/

URL4: Életfogytiglant kaptak a parndorfi halálkamion föbb embercsempészei. https://index. hu/belfold/2019/06/20/parndorfi_halalkamion_furgon_71_halott_menekult_masodfoku_itelet_embercsempeszet/

URL5: After the money: Prices for people smuggling on Central and Western Mediterranean routes. Frontex News 2020. https://frontex.europa.eu/media-centre/news/news-release/afterthe-money-prices-for-people-smuggling-on-central-and-western-mediterranean-routes-EHDfJg

\section{A cikk APA szabály szerinti hivatkozása}

Póczik Sz. (2021). Embercsempészés, nemzetközi bünügyi együttműködés, ítélethozatal. Belügyi Szemle, 69(10), 1851-1868. https://doi.org/10.38146/BSZ.2021.10.12 